удК 616.31-08-039.57-053.2”0/3”:616-089.5-031.81:612.82:612.262

DOI 10.11603/2311-9624.2019.3.10465

Cо. І. Коваль

Національний медичний університет імені О. О. Богомольця, м. Київ

okoval78@ukr.net

\title{
Оцінка оксидативного статусу головного мозку в дітей віком до 3 років на амбулаторному стоматологічному прийомі
}

\section{ІНФОРМАЦІЯ}

Надійшла до редакціï/Received: 02.09.2019 p.

Ключові слова: церебральна оксиметрія; стоматологічні маніпуляції; загальне знеболювання.

\section{АНОТАЦІЯ}

Резюме. Здоров’я нації у цілому залежить від здоров'я, зокрема підростаючого покоління. На жаль, соціально-побутові, економічні та екологічні умови, які склалися в країні останніми роками, не сприяють стабільності, а звідси і психологічній рівновазі дорослого населення, що, у свою чергу, негативно впливає на психоемоційний стан населення дитячого віку.

Мета дослідження - вивчити динаміку показників церебральної оксиметрії у дітей під час стоматологічного втручання під загальним знеболюванням в амбулаторних умовах та на амбулаторному прийомі.

Матеріали і методи. Проведено санацію порожнини рота у дітей віком до 3 років в амбулаторних умовах (72 дитини), в амбулаторних умовах під загальним знеболенням (38 дітей) на базі Стоматологічного медичного центру при Національному медичному університеті імені О. О. Богомольця. Оцінку кисневого насичення головного мозку проводили за допомогою неінвазивного методу нейромоніторингу - церебральної оксиметрії.

Результати досліджень та їх обговорення. При проведенні у дітей віком до 3-х років профілактичних заходів зниження $\mathrm{rSO}_{2}$ на стоматологічному амбулаторному прийомі відбувається лінійно без різких коливань і на 7 хвилині становить $(62,8 \pm 0,67) \%$, що складає 18,33 \% від початкового значення $\mathrm{rSO}_{2}(76,9 \pm 1,18)$ \%. Достовірної різниці між даними показниками при наявності «елементарних" $\left(\mathrm{rSO}_{2}=\left(63 \pm 0,01\left(7^{\prime}\right)-\downarrow 19,74\right) \%\right.$ та «криптогенних» $\left(\mathrm{rSO}_{2}=\left(62,7 \pm 0,94\left(7^{\prime}\right)\right.\right.$ - 17,39) \% фобій не виявлено. При проведенні процедури «лікування карієсу» на стоматологічному амбулаторному прийомі у дітей віком 0-3 роки встановлено зниження показника $\mathrm{rSO}_{2}$ до критичного рівня $-\downarrow 21,67 \%$ на 8 хв $\left(\mathrm{rSO}_{2}=60 \pm 2,09\right) \%$ від початкового значення $(76,6 \pm 2,6) \%$. Зниження $\mathrm{rSO}_{2}$ при стоматологічних маніпуляцій, пов’язаних з «лікуванням карієсу» відбувається в середньому 1,5 \% за 1хв. Тому вже на 7 хв проведення маніпуляції з приводу «лікування карієсу» $\mathrm{rSO}_{2}$ досягає початку критичного рівня і становить 20,17 \%. Достовірної різниці між даними показниками під час проведення процедури «лікування карієсу» при наявності "елементарних" ( $\left.\mathrm{rSO}_{2}=\left(60 \pm 2,13\left(8^{\prime}\right)-\downarrow 24,05\right) \%\right)$ та "криптогенних" $\left.\left(\mathrm{rSO}_{2}=60 \pm 2,31\left(8^{\prime}\right)-\downarrow 19,46\right) \%\right)$ фобій не виявлено. При проведенні процедури «лікування ускладненого карієсу» на стоматологічному амбулаторному прийомі у дітей віком 0-3 роки встановлено зниження показника $\mathrm{rSO}_{2}$ до критичного рівня - $20 \%$ на 6 хв $\left(\mathrm{rSO}_{2}=60 \pm 2,04\right) \%$ від початкового значення $(75 \pm 2,96) \%$. 
Достовірної різниці між даними показниками під час проведення процедури «лікування ускладненого карієсу» при наявності «елементарних" ( $\mathrm{rSO}_{2}=61 \pm 1,21\left(6^{\prime}\right)-\downarrow 21,39 \%$ \%) та «криптогенних" $\left(\mathrm{rSO}_{2}=58,9 \pm 2,29 \%\left(6^{\prime}\right)-\downarrow 18,65 \%\right)$ фобій також не виявлено. За результатами дослідження встановлено оптимальний час проведення різних стоматологічних маніпуляцій на амбулаторному стоматологічному прийомі у дітей віком від 0 до 3 років: «профілактичних" = 7-8 хв; «лікування карієсу» = 8 хв; «лікування ускладненого карієсу» = 6 хв. Аналіз результатів церебральної оксиметрії при санації порожнини рота в умовах загального знеболювання у дітей віком від 0 до 3 років показав: лінійне зниження показника $\mathrm{rSO}_{2}$ починається 330 хв. Найнижче значення $\mathrm{rSO}_{2}=(62,5 \pm 6,36) \%$ на 41 хв, при можливому min $\mathrm{rSO}_{2}=61,45 \%$. У середньому за 1 хв $\mathrm{rSO}_{2} \downarrow$ на 1,21\%. При прогнозі мінімально допустимого значення $\mathrm{rSO}_{2}$ досягне на 42 хв. Тому безпечний проміжок часу проведення стоматологічної санації під загальним знеболюванням в амбулаторних умовах у дітей віком від 0 до 3 років складає $(30 \pm 10)$ хв.

Висновки. 3 метою попередження виникнення когнітивних порушень на тлі виникнення гіпоксії головного мозку лікар-стоматолог дитячий зобов'язаний об'єктивно оцінити ризики психологічної травми та прийняти виважене рішення щодо умов надання стоматологічної допомоги. Вибір методу лікування зубів з урахуванням стадії їх розвитку залежить від об’єму стоматологічного втручання.

Вступ. Здоров’я нації у цілому залежить від здоров'я, зокрема підростаючого покоління. На жаль, соціально-побутові, економічні та екологічні умови, які склалися в країні останніми роками, не сприяють стабільності, а звідси і психологічній рівновазі дорослого населення, що, у свою чергу, негативно впливає на психоемоційний стан населення дитячого віку $[3,4,6]$. Така нестабільна психоемоційна сфера є гарним підгрунтям для розвитку когнітивних порушень підростаючого покоління на тлі органічних змін при порушеннях розвитку нейронних зв'язків головного мозку, які, головним чином, активно утворюються в дитячому віці [2, 5, 9, 12-14].

Враховуючи високу інтенсивність та розповсюдження карієсу серед дитячого населення не можна недооцінювати роль стресу на стоматологічному прийомі у виникненні когнітивних порушень [7, 11].

Відомо, що стресова ситуація супроводжується підвищенням частоти серцевого пульсу, а також артеріального тиску. При функціональних змінах у серцево-судинній системі на стоматологічному прийомі приєднуються механічні фактори впливу на дихальні шляхи (робота стоматолога безпосередньо в зоні дихальних шляхів, положення пацієнта в кріслі, тощо), що, у свою чергу, зумовлюють обмеження доступу повітря (зниження парціального тиску кисню у повітрі на вдосі, стис- кання краніальних судин унаслідок зміни положення шиї тощо). Також велику роль відіграють болісні стоматологічні маніпуляції, які стимулюють та підтримують вже запущені фізіологічні механізми стресової ситуації (препарування, вскриття рогу пульпи, стах при місцевій анестезії). Сукупність вищезазначених факторів, що лягли в основу незрілої імунної системи дитини, морфологічних та фізіологічних особливостей вікової будови дихальних шляхів можуть негативно впливати на насичення киснем судин, зокрема головного мозку, що є однією з головних причин виникнення когнітивних змін $[5,13,16,19]$.

3 метою збереження психологічної рівноваги дитини та іï когнітивних функцій під час лікування зубів, все частіше лікарі-стоматологи надають перевагу санації порожнини рота в амбулаторних умовах під загальним знеболюванням [17].

Потрібно зазначити, що надання стоматологічної допомоги в умовах загального знеболювання не завжди вирішує проблему порушення когнітивних функцій головного мозку. В даному випадку залишається ризик виникнення органічних порушень головного мозку на тлі гіпоксії/ішемії. Адже замість гормону стресу в даному випадку приєднується дія лікарських препаратів.

Отже, лікування зубів в амбулаторних умовах під загальним знеболюванням $є$ захистом 
дитини від стресових факторів, але не виключає порушень когнітивних функцій на тлі органічного ураження головного мозку $[5,13,14$, 17]. Вищезазначені фактори зобов'язують лікаря об'єктивно оцінити ризики психологічної травми на тлі стоматологічного статусу та прийняти виважене рішення щодо умов надання стоматологічної допомоги, об'єму стоматологічного втручання та вибору методу лікування зубів з урахуванням стадії їх розвитку.

Для об'єктивної оцінки кисневого статусу головного мозку, з метою профілактики виникнення порушень когнітивних функцій на тлі кисневого голодування на стоматологічному прийомі доцільно застосовувати метод оцінки кисневого насичення головного мозку - церебральну оксиметрію [1, 15, 18, 19].
Метою дослідження було вивчити динаміку показників церебральної оксиметрії у дітей під час стоматологічного втручання під загальним знеболюванням в амбулаторних умовах та на амбулаторному прийомі.

Матеріали і методи. Проведено санацію порожнини рота у дітей віком до 3 років в амбулаторних умовах (72 дитини), в амбулаторних умовах під загальним знеболюванням (38 дітей) на базі Стоматологічного медичного центру при Національному медичному університеті імені О. О. Богомольця.

Дітей поділили на групи з урахуванням темпераменту (Томас та Чесс, 1997) та виду стоматологічних маніпуляцій (табл.). Враховували також наявність «елементарних» та «криптогенних» фобій [17].

таблиця. Поділ дітей на групи, яким проведено санацію порожнини рота: на амбулаторному прийомі та на амбулаторному прийомі під загальним знеболюванням

\begin{tabular}{|c|c|c|c|c|}
\hline \multirow{2}{*}{ Темперамент } & \multicolumn{4}{|c|}{ Вид стоматологічних маніпуляцій } \\
\cline { 2 - 5 } & $\begin{array}{c}\text { неінвазивні методи } \\
\text { профілактики }\end{array}$ & $\begin{array}{c}\text { лікування } \\
\text { карієсу }\end{array}$ & $\begin{array}{c}\text { лікування ускдад- } \\
\text { неного карієсу }\end{array}$ & усього \\
\hline Легкий & $5 / 8$ & $7 / 8$ & $6 / 8$ & $18 / 8$ \\
\hline Складний & $6 / 11$ & $10 / 11$ & $10 / 11$ & $26 / 11$ \\
\hline Довго розігрівається & $8 / 19$ & $10 / 19$ & $10 / 19$ & $28 / 19$ \\
\hline Усього & $19 / 38$ & $27 / 38$ & $26 / 38$ & $72 / 38$ \\
\hline
\end{tabular}

Примітка. Характеристика поведінки дитини з різним темпераментом: легкий темперамент - діти зі стабільною психікою, легко адаптуються в різних ситуаціях, в тому числі невідомих досі. Складний темперамент - діти, які складно адаптуються у різних ситуаціях. Довго розігрівається - діти, які тяжко адаптуються в різних ситуаціях, не проявляють активності.

Оцінку кисневого насичення головного мозку в дітей під час проведення стоматологічних маніпуляцій на амбулаторному прийомі проводили за допомогою неінвазивного методу нейромоніторингу - церебральної оксиметрії. Даний метод дозволяє оцінити оксидативний статус (насичення гемоглобіну киснем) крові церебральних судин із метою моніторингу експліцитності церебральної ішемії та толерантності до гіпоксії головного мозку, що є причиною виникнення когнітивних порушень.

Апарат для моніторингу газу крові: 4-канальний регіональний оксиметр 3 технікою EQUANOXTM, технікою безпровідного зв'язку Bluetooth та RS-232 (модель 7600) (свідоцтво про державну реєстрацію № 12580/2013. Виробник: Nonin Medical, Inc., USA).

У літературі описані суперечливі дані щодо норм показників церебральної оксиметрії $\left(\mathrm{rSO}_{2}\right)$ у дітей, що може бути пов'язано із особливостями індивідуального фізичного розви- тку дитини та віковими особливостями розвитку органів та систем $[1,15,18,19]$.

Тому зниження показників $\mathrm{rSO}_{2}$ визначали від початкового найвищого значення визначеної групи. Для прогнозу виникнення когнітивних порушень унаслідок органічних порушень головного мозку ми використовували дослідження J. Meixensberger et al. (1998) [15], при якому: різке $\downarrow \mathrm{rSO}_{2} \geq 20 \%$ відповідає кисневому голодуванню унаслідок перфузії головного мозку, що може бути при стисканні краніальних судин унаслідок зміни положення шиї; $\downarrow \mathrm{rSO}_{2} \geq 20 \%$ відповідає підвищенню метаболізму мозкової тканини; $\downarrow \mathrm{rSO}_{2} \geq 25 \%$ (15-30 хв) відповідає підвищенню тканинної екстракції кисню 3 крові, що припливає, і свідчить про наявність гіпоксії мозкової тканини; $\downarrow \mathrm{rSO}_{2} \geq 25 \%$ ( $\geq 30$ хв.), або $\downarrow \mathrm{rSO}_{2} \geq 40 \%$ відповідає наявності ішемії мозку; $\downarrow \mathrm{rSO}_{2} \geq 40 \%$ відповідає наявності грубих неврологічних розладів або наявності епілептичної активності. 
Результати досліджень та їх обговорення. Динаміку показників $\mathrm{rSO}^{2}$ у дітей віком до 3 років під час проведення санації порожнини рота на амбулаторному прийомі при різних видах стоматологічного втручання представлено в рисунку 1.

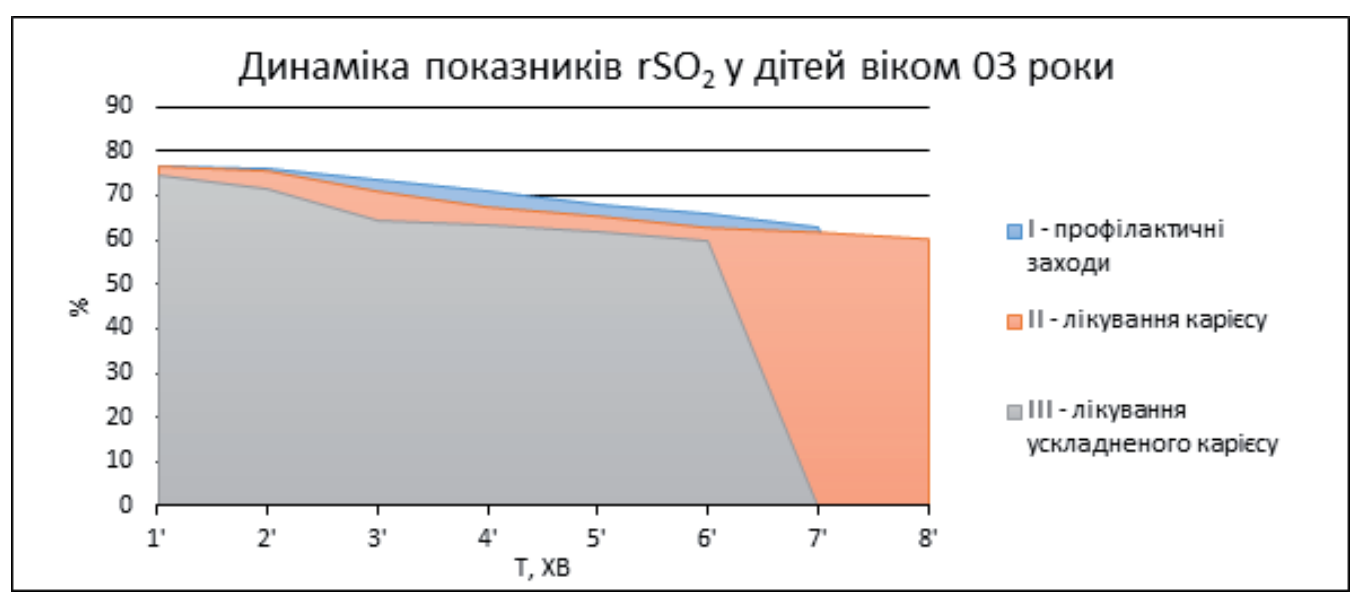

Профілактичні заходи: $\mathrm{NrSO}_{2}=(76,9 \pm 1,18) \% ; \max =(94,4 \pm 6,48) \% ; \min =(61,4 \pm 0,96) \%$. $\mathrm{rSO}_{2}: \max =\left(76,9 \pm 1,18\left(1^{\prime}\right) \%\right.$; $\min =\left(62,8 \pm 0,67\left(7^{\prime}\right)-\downarrow 18,33\right) \%$

Лікування карієсу: $\mathrm{NrSO}_{2}=(76,6 \pm 2,6) \%$; $\max =(91,9 \pm 3,13) \%$; $\min =(61,2 \pm 2,07) \%$.

$\mathrm{rSO}_{2}: \max =\left(76,6 \pm 2,6\left(1^{\prime}\right)\right) \%$; $\min =\left(60 \pm 2,09\left(8^{\prime}\right)-\downarrow 21,67\right) \%$

Лікування ускладненого карієсу: $\mathrm{NrSO}_{2}=(75 \pm 2,96) \%$; $\max =(90 \pm 3,55) \%$; $\min =(60 \pm 2,37) \%$. $\mathrm{rSO}_{2}: \max =\left(75 \pm 2,96\left(1^{\prime}\right) \%\right.$; $\min =\left(60 \pm 2,04\left(6^{\prime}\right)-\downarrow 20\right) \%$

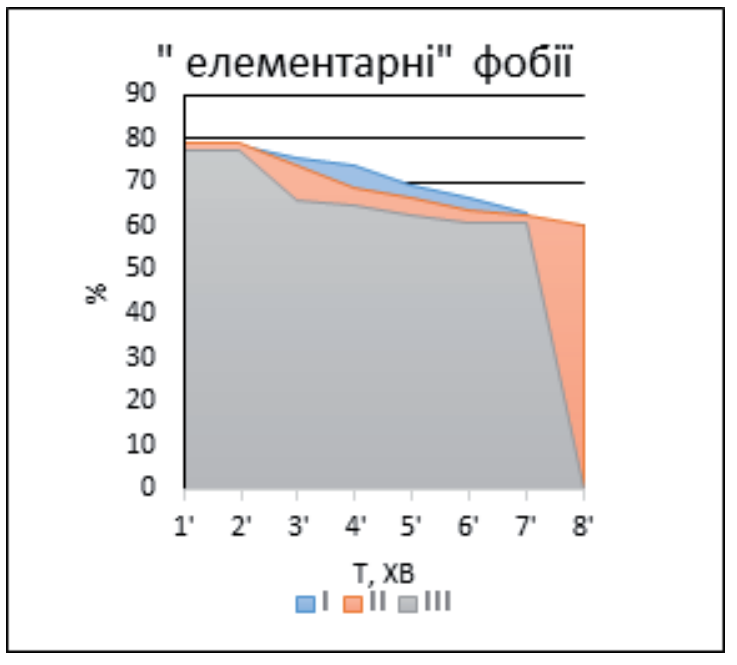

Профілактичні заходи:

$\mathrm{NrSO}_{2}=(77,8 \pm 0,83) \%: \max =(97,7 \pm 0,96) \%$;

$\min =(62,2 \pm 0,75) \% \cdot \mathrm{rSO}_{2}: \max =\left(78,5 \pm 1,34\left(2^{\prime}\right)\right) \%$; $\min =\left(63 \pm 0,01\left(7^{\prime}\right)-\downarrow 19,74\right) \%$.

Лікування карієсу:

$\mathrm{NrSO}_{2}=(78,6 \pm 1,82) \%: \max =(94,3 \pm 2,19) \%$; $\min =(62,9 \pm 1,46) \% . \mathrm{rSO}_{2}: \max =(79 \pm 1,82(2)) \%$; $\min =\left(60 \pm 2,13\left(8^{\prime}\right)-\downarrow 24,05\right) \%$.

Лікування ускладненого карієсу:

$\mathrm{NrSO}_{2}=(77,6 \pm 1,6) \%: \max =(93,1 \pm 1,92) \%$;

$\min =(62,1 \pm 1,28) \%$. $\mathrm{rSO}_{2}: \max =\left(77,6 \pm 1,6\left(1^{\prime}-2^{\prime}\right)\right)$

$\%$; $\min =\left(61 \pm 1,21\left(6^{\prime}\right)-\downarrow 21,39\right) \%$.

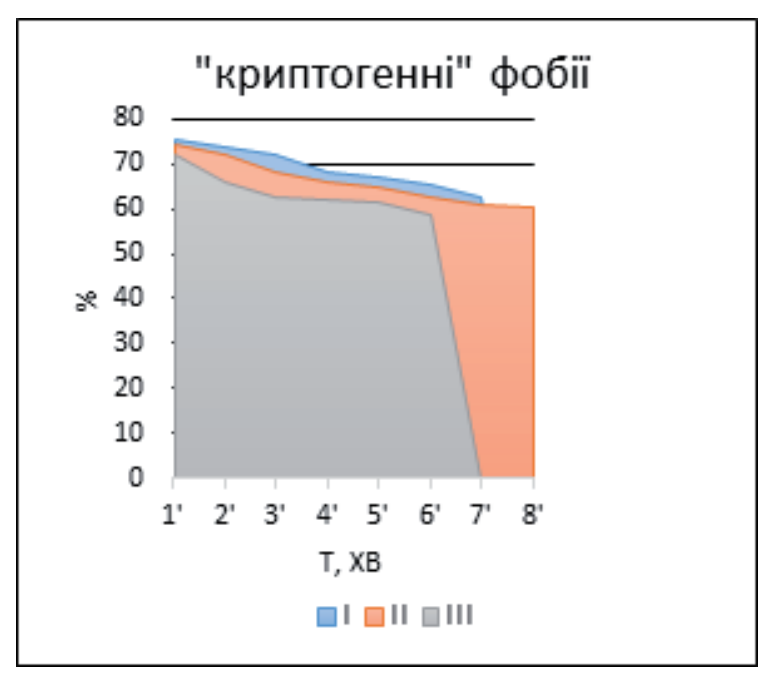

Профілактичні заходи:

$\mathrm{NrSO}_{2}=(75,9 \pm 0,46) \%: \max =(91,1 \pm 0,55) \%$; $\min =(60,7 \pm 0,36) \% . \mathrm{rSO}_{2}: \max =\left(75,9 \pm 0,46\left(1^{\prime}\right)\right) \%$; $\min =\left(62,7 \pm 0,94\left(7^{\prime}\right)-\downarrow 17,39\right) \%$.

Лікування карієсу:

$\mathrm{NrSO}_{2}=(74,5 \pm 1,36) \%: \max =(89,4 \pm 1,67) \%$; $\min =(59,6 \pm 1,07) \% . \mathrm{rSO}_{2}: \max =\left(74,5 \pm 1,36\left(1^{\prime}\right)\right) \%$; $\min =\left(60 \pm 2,31\left(8^{\prime}\right)-\downarrow 19,46\right) \%$.

Лікування ускладненого карієсу: $\mathrm{NrSO}_{2}=(72,4 \pm 1,23) \%: \max =(86,9 \pm 1,48) \%$; $\min =(57,9 \pm 0,99) \% . \mathrm{rSO}_{2}: \max =\left(72,4 \pm 1,23\left(1^{\prime}\right)\right) \%$; $\min =\left(58,9 \pm 2,29\left(6^{\prime}\right)-\downarrow 18,65\right) \%$.

Puc. 1. Динаміка показників $\mathrm{rSO}_{2}$ у дітей віком 0-3 роки під час проведення санації порожнини рота на амбулаторному прийомі при різних видах стоматологічного втручання. 
При проведенні профілактичних заходів у дітей віком до 3 років зниження $\mathrm{rSO}_{2}$ відбувається лінійно без різких коливань і на 7 хв становить $(62,8 \pm 0,67) \%$, що складає $18,33 \%$ від початкового значення $\mathrm{rSO}_{2}(76,9 \pm 1,18) \%$. Достовірної різниці даних показників при наявності «елементарних» $\left(\mathrm{rSO}_{2}=63 \pm 0,01\left(7^{\prime}\right)-\downarrow 19,74\right) \%$ та «криптогенних" $\left(\mathrm{rSO}_{2}=\left(62,7 \pm 0,94\left(7^{\prime}\right)-\downarrow 17,39\right) \%\right.$ фобій не виявлено.

Даний факт можна пояснити віковими психологічними особливостями. Дітям у такому віці неможливо пояснити хід майбутніх процедур. У них домінує страх від втручання в особистий простір чужої для них людини (стоматолога), адже до моменту відвідування стоматолога дитина перебувала та іï повністю обслуговували лише батьки й оточували лише знайомі та близькі для неї люди. I таке нововведене втручання в особистий простір дитина сприймає як страх втрати захисту близьких людей $[8,10]$. Стрес, вікові особливості дихальних шляхів, робота стоматолога поблизу верхніх дихальних шляхів - усі ці фактори впливають на зниження насичення киснем тканин головного мозку. Зауважимо, що зниження $\mathrm{rSO}_{2}$ відбувається близько $2 \%$ за 1 хв. За даними J. Meixensberger et al., суттєве значення має $\downarrow \mathrm{rSO}_{2} \geq 20-30 \%$ упродовж 15-30 хв. Таким чином, при проведенні профілактичних процедур показник $\mathrm{rSO}_{2}$ досягне початку критичного значення на 8 хв.

Тому 3 метою збереження когнітивних функцій на тлі органічних порушень під час стресу на стоматологічному прийомі рекомендовано проводити профілактичні процедури дітям віком від 0 до 3 років 7-8 хв.

При проведенні процедури «лікування карієсу» в дітей віком 0-3 роки встановлено зниження показника $\mathrm{rSO}_{2}$ до критичного рівня $-\downarrow 21,67 \%$ на 8 хв $\left(\mathrm{rSO}_{2}=(60 \pm 2,09) \%\right.$ від початкового значення $(76,6 \pm 2,6) \%$. Зменшення $\mathrm{rSO}_{2}$ при стоматологічних маніпуляціях, пов’язаних з «лікуванням карієсу», відбувається в середньому 1,5 \% за 1хв. Тому вже на 7 хв проведення маніпуляції з приводу «лікування карієсу» rSO2 досягає початку критичного рівня і становить 20,17\%.

Достовірної різниці даних між показниками під час проведення процедури «лікування карієсу" при наявності “елементарних" $\left(\mathrm{rSO}_{2}=\left(60 \pm 2,13\left(8^{\prime}\right)-\downarrow 24,05\right) \%\right.$ та «криптогенних" $\left(\mathrm{rSO}_{2}=60 \pm 2,31\left(8^{\prime}\right)-\downarrow 19,46\right) \%$ фобій не виявлено.

При проведенні процедури «лікування ускладненого карієсу» в дітей віком 0-3 роки встановлено зниження показника $\mathrm{rSO}_{2}$ до критичного рівня $-\downarrow 20 \%$ на 6 хв $\left(\mathrm{rSO}_{2}=(60 \pm 2,04) \%\right)$ від початкового значення $(75 \pm 2,96) \%)$.

Достовірної різниці між даними показниками під час проведення процедури «лікування ускладненого карієсу» при наявності «елементарних» $\left(\mathrm{rSO}_{2}=61 \% \pm 1,21\left(6^{\prime}\right)-\downarrow 21,39 \%\right)$ та «криптогенних» $\left(\mathrm{rSO}_{2}=58,9 \pm 2,29 \%\left(6^{\prime}\right)-\downarrow 18,65 \%\right)$ фобій також не виявлено.

Більш низьке зниження $\mathrm{rSO}_{2}$ при проведенні процедур «лікування карієсу» та «лікування ускладненого карієсу» в групі дітей із наявністю «криптогенних" фобій пояснюється більш низьким його початковим значенням порівняно $з$ групою дітей, які мали «елементарні» фобії.

Початкове значення $\mathrm{rSO}_{2}$ при «лікуванні карієсу» в групі дітей, які мали «елементарні» фобії, становить $(79 \pm 1,82) \%$, «криптогенні» фобії - $(74,5 \pm 1,36) \%$; при «лікуванні ускладненого карієсу» даний показник склав $(77,6 \pm 1,6) \%$ та $(72,4 \pm 1,23) \%$ відповідно.

Зниження показника $\mathrm{rSO}_{2}$ при наявності «криптогенних" фобій можна пояснити «відкладанням у пам'яті» негативного досвіду стоматологічного втручання при проведенні болісних процедур [2, 9, 11].

Отже, рекомендований час проведення стоматологічних маніпуляції з приводу лікування карієсу та його ускладнень на амбулаторному прийомі у дітей віком 0-3 роки складає 8 та 6 хв відповідно.

Динаміку показників $\mathrm{rSO}_{2}$ у дітей віком 03 роки під час проведення санації порожнини рота на амбулаторному прийомі під загальним знеболюванням представлено на рисунку 2.

Як видно з рисунка, лінійне зниження показника $\mathrm{rSO}_{2}$ починається 330 хв. Найнижче значення $\mathrm{rSO}_{2}=(62,5 \pm 6,36) \%$ на $41 \mathrm{xв}$, при можливому min $\mathrm{rSO}_{2}=61,45 \%$. У середньому за $1 \mathrm{xB} \mathrm{rSO}_{2} \downarrow-$ на 1,21 \%. При прогнозі мінімально допустимого значення $\mathrm{rSO}_{2}$ досягне на 42 хв. Тому безпечний проміжок часу проведення стоматологічної санації під загальним знеболюванням в амбулаторних умовах у дітей віком 0-3 роки складає $(30 \pm 10)$ хв.

Отже, церебральна оксиметрія $\epsilon$ об'єктивним методом оцінки оксидативного статусу головного мозку при проведенні стоматологічної санації в амбулаторних умовах та в амбулаторних умовах під загальним знеболюванням, що дає можливість своєчасної корекції дій лікаря з метою збереження роз- 


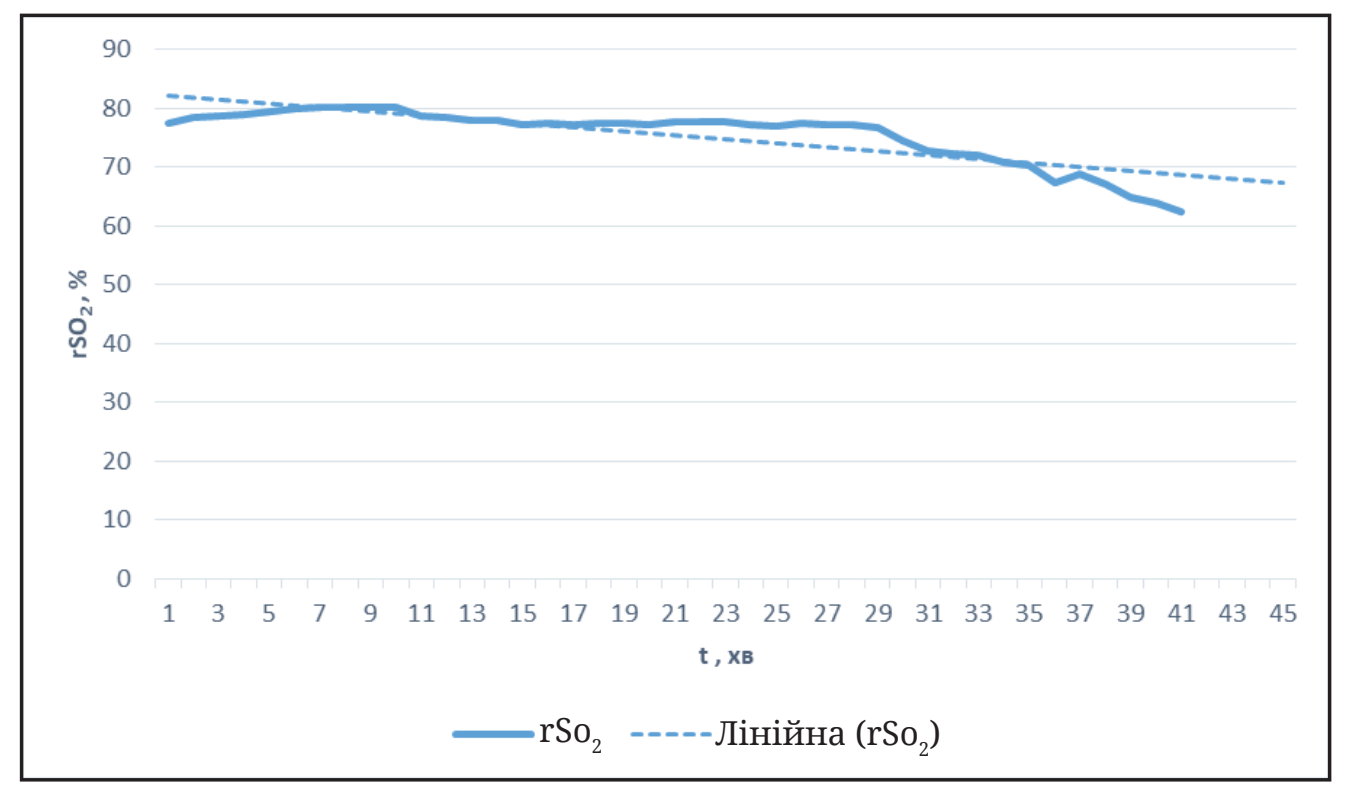

Puc. 2. Показники $\mathrm{rSO}_{2}$ У дітей віком 0-3 роки в період санації порожнини рота під загальним знеболюванням в амбулаторних умовах.

витку когнітивних функцій дитини в майбутньому.

Висновки. 1. 3 метою збереження когнітивних функцій на тлі органічних порушень під час стресу проведення стоматологічних маніпуляцій на амбулаторному прийомі мають обмеження за часом та враховують болісність процедури.

2. Оптимальний час проведення стоматологічних маніпуляцій на амбулаторному стоматологічному прийомі у дітей віком 0-3 роки не залежить від наявності «елементарних» та "криптогенних" фобій: "профілактичних" = 7-8 хв; «лікування карієсу» = 7 хв; «лікування ускладненого карієсу» $=6$ хв.

3. Оптимальний час проведення стоматологічної санації в амбулаторних умовах під загальним знеболюванням дітям віком 0-3 роки $=(30 \pm 10) \mathrm{XB}$.

4. 3 метою попередження виникнення когнітивних порушень на тлі виникнення гі- поксії головного мозку лікар-стоматолог дитячий зобов'язаний об'єктивно оцінити ризики психологічної травми та прийняти виважене рішення щодо умов надання стоматологічної допомоги. Вибір методу лікування зубів з урахуванням стадії їх розвитку залежить від об’єму стоматологічного втручання.

Перспективи подалыших досліджень. Вивчити динаміку показників церебральної оксиметрії під час проведення різних стоматологічних маніпуляцій на амбулаторному стоматологічному прийомі та під час виконання санації порожнини рота під загальним знеболюванням у дітей різного віку. Встановити безпечний проміжок часу для проведення стоматологічних маніпуляцій різного характеру на стоматологічному амбулаторному прийомі та час проведення санації порожнини рота під загальним знеболюванням у дітей різного віку, залежно від їх типу темпераменту та виду фобій.

\section{(С). И. Коваль}

Национальный медицинский университет имени А. А. Богомольца, г. Киев

\section{Оценка оксидативного статуса головного мозга у детей в возрасте до 3 лет на амбулаторном стоматологическом прийоме}

Резюме. Здоровье нации в целом зависит от здоровья, в частности подрастающего поколения. К сожалению, социально-бытовые, экономические и экологические условия, которые сложились в стране в последние годы, не способствуют стабильности, а отсюда и психологической равновесии взрос- 
лого населения, что, в свою очередь, негативно влияет на психоэмоциональное состояние населения детского возраста

Цель исследования изучить динамику показателей церебральной оксиметрии у детей во время стоматологического вмешательства под общим обезболиванием в амбулаторных условиях и на амбулаторном приеме.

Материалы и методы. Проведена санация полости рта у детей до 3 лет в амбулаторных условиях (72 ребенка), в амбулаторных условиях под общим обезболиванием (38 детей) на базе Стоматологического медицинского центра при Национальном медицинском университете имени А. А. Богомольца. Оценку кислородного насыщения головного мозга проводили с помощью неинвазивного метода нейромониторинга - церебральной оксиметрии.

Результаты исследований и их обсуждение. При проведении у детей в возрасте до 3 лет профилактических мероприятий снижение $\mathrm{rSO}_{2}$ на стоматологическом амбулаторном приеме происходит линейно без резких скачков и на 7 мин становит $(62,8 \pm 0,67)$ \% что составляет 18,33 \% от начального значения $\mathrm{rSO}_{2}(76,9 \pm 1,18) \%$. Достоверной разницы между данными показателями при наличии «элементарных» $\left(\mathrm{rSO}_{2}=\left(63 \pm 0,01\left(7^{\prime}\right)-\downarrow 19,74\right) \%\right)$ и «криптогенных» $\left(\mathrm{rSO}_{2}=\left(62,7 \pm 0,94\left(7^{\prime}\right)-\downarrow 17,39\right) \%\right.$ фобий не выявлено. При проведении процедуры «лечения кариеса» на стоматологическом амбулаторном прийоме у детей в возрасте 0-3 года установлено снижение показателя $\mathrm{rSO}_{2}$ до критического уровня - $\downarrow 21,67 \%$ на 8 мин $\left(\mathrm{rSO}_{2}=60 \pm 2,09\right) \%$ от начального значения $(76,6 \pm 2,6) \%$. Сижение $\mathrm{rSO}_{2}$ при стоматологических манипуляциях при «лечении кариеса» происходит в среднем 1,5 \% за 1мин. Поэтому уже на 7 мин проведения манипуляции «лечения кариаеса» $\mathrm{rSO}_{2}$ достигает начала критического уровня и составляет 20,17 \%. Достоверной разницы между данными показателями во время прове-

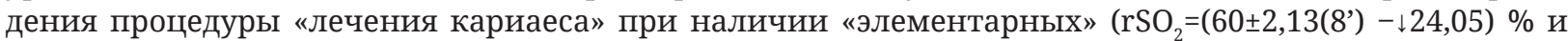
«криптогенных» $\left(\mathrm{rSO}_{2}=\left(60 \pm 2,31\left(8^{\prime}\right)\right.\right.$ - 19,46$)$ \%) фобий не выявлено. При проведении процедуры «лечения осложненного кариеса» на стоматологическом амбулаторном прийоме у детей в возрасте 0-3 года установлено снижение показателя $\mathrm{rSO}_{2}$ до критического уровня $-\downarrow 20 \%$ на 6 мин $\left(\mathrm{rSO}_{2}=(60 \pm 2,04) \%\right.$ от начального значения $(75 \pm 2,96) \%$. Достоверной разницы между данными показателями во время процедуры «лечения осложненного кариеса» при наличии «элементарных" $\left(\mathrm{rSO}_{2}=(61 \pm 1,21(6\right.$ ') $-\downarrow 21,39) \%$ и «криптогенных» $\left(\mathrm{rSO}_{2}=(58,9 \pm 2,29)\left(6^{\prime}\right)-\downarrow 18,65\right)$ фобий тоже не выявлено. По результатам исследования установлено оптимальное время проведения различных стоматологических манипуляций на амбулаторном стоматологическом приеме у детей в возрасте до 3 лет: «профилактических» = 7-8 мин; «лечение кариеса» = 8 мин; «лечение осложненного кариеса» = 6 мин. Анализ результатов церебральной оксиметрии при санации полости рта в условиях общего обезболивания у детей в возрасте от 0 до 3 лет показал: линейное снижение показателя $\mathrm{rSO}_{2}$ начинается с 30 мин. Самое низкое значение $\mathrm{rSO}_{2}=(62,5 \pm 6,36) \%$ на 41 мин, при возможном min $\mathrm{rSO}_{2}=61,45 \%$. В среднем за $1 \mathrm{мин}$ $\mathrm{rSO}_{2} \downarrow$ на 1,21 \%. При прогнозе минимально допустимого значения $\mathrm{rSO}_{2}$ достигнет на 42 мин. Поэтому безопасный промежуток времени проведения стоматологической санации под общим обезболива-

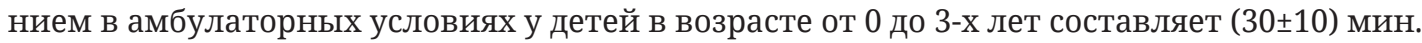

Выводы. С целью предупреждения возникновения когнитивных нарушений на фоне возникновения гипоксии головного мозга врач-стоматолог детский обязан обьективно оценить риски возникновения писхологической травмы и принять решение касательно условий оказания стоматологической помощи. Выбор метода лечения зубов с учетом стадии их развития зависит от обьема оказания стоматологической помощи.

Ключевые слова: церебральная оксиметрия; стоматологические манипуляции; общее обезболивание.

\section{C) O. I. Koval}

O. Bohomolets National Medical University, Kyiv

\section{Assessment of the oxidative status of the brain in children under the age of 3 years on an outpatient basis dental appointment}

Summary. The health of the nation as a whole depends on the health, in particular of the younger generation. Unfortunately, the social, economic and environmental conditions that have developed in the country in recent years do not contribute to stability, and hence the psychological balance of the adult population, which, in turn, negatively affects the psychoemotional state of the child population.

The aim of the study - to learn the dynamics of cerebral oximetry in children during dental interventions under general anesthesia on an outpatient basis and on an outpatient appointment; establish a safe time 
interval for dental manipulations of different nature at the dental outpatient reception and the time of rehabilitation of the oral cavity under general anesthesia in children aged 0 to 3 years.

Materials and Methods. The oral cavity was rehabilitated in children under 3 years of age on an outpatient basis (72 children) under general anesthesia (38 children) at the Dental Medical Center of O. Bohomolets National Medical University. Assessment of oxygen saturation of the brain was performed using a noninvasive neuromonitoring method - cerebral oximetry.

Results and Discussion. When carrying out in children under 3 years of preventive measures the reduction of $\mathrm{rSO}_{2}$ at the dental outpatient reception is linear without sharp fluctuations and at 7 minute makes $(62.8 \pm 0.67) \%$ which is $18.33 \%$ from the initial value of $\mathrm{rSO}_{2}(76.9 \pm 1.18) \%$. Significant difference of these indicators in the presence of "elementary" $\left(\mathrm{rSO}_{2}=(63 \pm 0.01) \%\left(7^{\prime}\right)-\downarrow 19.74 \%\right)$ and "cryptogenic" $\left(\mathrm{rSO}_{2}=(62.7 \pm 0.94) \%\left(7^{\prime}\right)-\downarrow\right.$ $17.39 \%)$ of phobias were not detected.

When performing the procedure of "caries treatment" at the dental outpatient reception in children aged 0-3 years, a decrease in the $\mathrm{rSO}_{2}$ indicator to a critical level $-\downarrow 21.67 \%$ for 8 minutes $\left(\mathrm{rSO}_{2}=(60 \pm 2.09) \%\right.$ from the initial value of (76.6 \pm 2.6$) \%$. Decrease in $\mathrm{rSO}_{2}$ in dental caries related to dental caries is an average of $1.5 \%$ per minute. Therefore, for 7 minutes. manipulation of the caries treatment $\mathrm{rSO}_{2}$ reaches a critical level of $20.17 \%$. Significant difference of these indicators during the procedure of "caries treatment" in the presence of "elementary" $\left(\mathrm{rSO}_{2}=(60 \pm 2.13) \%\left(8^{\circ}\right)-\downarrow 24.05 \%\right)$ and "cryptogenic" $\left(\mathrm{rSO}_{2}=(60 \pm 2.31) \%(8)-\downarrow 19.46 \%\right)$ of phobias were not detected. During the procedure of "treatment of complicated caries" at the dental outpatient reception in children aged 0-3 years, a decrease in $\mathrm{rSO}_{2}$ to a critical level $-\downarrow 20 \%$ at 6 minute $\left(\mathrm{rSO}_{2}=(60 \pm 2.04) \%\right.$ from the initial value of $(75 \pm 2.96) \%$.

Significant difference of these indicators during the procedure of "treatment of complicated caries" in the presence of "elementary" $\left(\mathrm{rSO}_{2}=(61 \pm 1.21) \%\left(6^{\circ}\right)-\downarrow 21.39 \%\right)$ and "cryptogenic" $\left(\mathrm{rSO}_{2}=(58.9 \pm 2.29) \%\left(6^{`}\right)-\downarrow\right.$ $18.65 \%)$ of phobias were also not detected.

According to the results of the study, the optimal time of various dental manipulations at the outpatient dental reception in children from 0 to 3 years was established: "preventive" $=7-8$ minutes; "caries treatment" $=8$ minutes; "treatment of complicated caries" = $6 \mathrm{~min}$.

Analysis of the results of cerebral oximetry in the rehabilitation of the oral cavity in conditions of general anesthesia in children aged 0 to 3 years showed: a linear decrease in $\mathrm{rSO}_{2}$ begins from $30 \mathrm{~min}$. The lowest $\mathrm{rSO}_{2}$

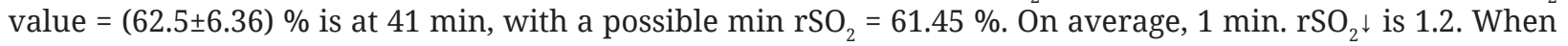
predicted, the minimum permissible value of $\mathrm{rSO}_{2}$ will reach at 42 minute. Therefore, a safe time interval for dental rehabilitation under general anesthesia in an outpatient setting in children aged 0 to 3 years is $(30 \pm 10)$ minutes.

Conclusions. Therefore, in order to prevent the occurrence of cognitive impairment against the background of brain hypoxia, the dentist is obliged to objectively assess the risks of psychological trauma against the background of the dental status and make a well-informed decision on the conditions of dental care. The choice of dental treatment based on the stage of their development depends on the amount of dental intervention.

Key words: cerebral oximetry; dental manipulations; general anesthesia.

\section{СПИСОК ЛІТЕРАТУРИ}

1. Аксельрод Б. А. Мониторинг оксигенации тканей: новая волна в палитре анестезиолога / Б. А. Аксельрод // Отделение интенсивной терапии. - 2012. № 1. - С. 8-14.

2. Безруких М. М. Возрастная физиология (физиология развития ребенка) : учеб. пособ. для студ. высш. пед. учеб. заведений / М. М. Безруких, В. Д. Сонкин, Д. А. Фарбер. - М. : Издательский центр «Академия», 2003. $-416 \mathrm{c}$.

3. Гузєєва Т. С. Сучасні тенденції психічного здоров’я населення та заходи щодо його вдосконалення / Т. С. Гузєєва // Психічне здоров’я. - 2004. - № 2 (3). C. $4-8$.

4. Degarle P. Preservation of psychic health in the world: challenges and priorities in developing countries / P. Degarle. -2001 . -536 p.

5. Давидова Н. С. Можливі критерії прогнозування порушення мозкового кровообігу під час наркозу
/ Н. С. Давидова // Відділення інтенсивної терапії. 2004. - № 5. - С. 232-234.

6. Основи законодавства України про охорону здоров’я [Редакційний вид 31.12.2017 згідно Закону України від 14.11.2017 № 2206. Закон України від 19.11.1992 № 2801-XII.]. - Закон України.

7. Киселева О. Г. Профилактика стоматологического страха. Часть І. / О. Г. Киселева // Детская стоматология и профилактика. - 2006. - № 1-2. - С. 54-61.

8. Співпраця «дитина-стоматолог-батьки» - гарантія успішного лікування // В. М. Кузнєцов, О. І. Прохно, П. Б. Коваль, О. М. Косенко // Неонатологічна хірургія та перинатальна медицина. - 2015. - № 4 (18). - С. 19-26.

9. Микадзе У. В. Нейропсихология детского возраста / У. В. Микадзе. - ПБ. : Питер, 2008. - 288 с.

10. Максименко С. Д. Загальна психологія : навч. посіб. - 2-ге вид. перероб. та доп. / С. Д. Максимен- 
ко. - К. : «Центр навчальної літератури», 2004. 272 c.

11. Стресс и патология : метод. разраб. для самостоятельной работы студ. лечеб. и педиатр. факультетов / под ред. Г. В. Поядина. - М. : РГМУ, 2009. - 23 с.

12. Burkhart C. S. Can postoperative cognitive dysfunction be avosded? / C. S. Burkhart, L. A. Steiner // Hosp. Pract. - 1995. - 2012. Vol. 40 (1). - P. 214-223.

13. Лобов М. Периоперационная профилактика ранней когнитивной дисфункции у детей. Медицина интенсивной терапии / М. Лобов, А. Князев, А. Ове3ов. $-2010 .-36$ c.

14. Meixensberger J. Monitoring of cerebral oxygenation by near infrared spectroscopy vs brain tissue PO2 and cerebral perfusion pressure following severe head injury / J. Meixensberger, J. Dings, B. Hamelbeck // Proc. Int. Cereb. Hemodyn. Symp. of North America. - 1995. - June, 06.

15. Mchedlishvili G. I. Arterial behavior and blood
Circulation in the Brain / G. I. Mchedlishvili. - NY. : Plenum Press - 1998. - P. 56-57.

16. Prokhno O. I. Clinikal and psychological basis of indications for oral cavity sanation in children of different ages under general anesthesia : International conference Materials Methods and Technologies, Bulgaria, 2014, 08.

17. New noninvasive methods for assessing brain oxygenation and haemodynamics / E. O. R. Reynolds, J. S. Wyatt, D. Azzopardi [et al.] // Brit. Med. Bull. - 1988. - P. 1052-1075.

18. Cerebral oxygenation is associated with neurodevelopmental outcome of preterm children at age 2-3 years / E. A. Verhagen, K. N. Van Braeckel, van C. N. der Veere [et al.] // Dev. Med. Child Neurol. - 2015. - Vol. 57 (5). - P. 449-455.

19. Яхно Н. Н. Когнитивные нарушения. Неврология : национальное руководство / Н. Н. Яхно, В. В. Захаров. $-2010 .-$ T. 10. - C. 532-547.

\section{REFERENCES}

1. Akselrod, B.A. (2012). Monitoring oksigenatsii tkaney: novaya volna $\mathrm{v}$ palitre anesteziologa [Monitoring tissue oxygenation: a new wave in the palette of the anesthetist]. Otdeleniye intensivnoy terapii - Intensive Care Unit, 1, 8-14 [in Russian].

2. Bezrukikh, M.M., Sonkin, V.D., \& Farber, D.A. (2003). Vozrastnaya fiziologiya (Fiziologiya razvitiya rebenka): ucheb. posobiye dlya stud. vyssh. ped. ucheb. zavedeniy [Age physiology (Physiology of child development): textbook]. Moscow: Izdatelskiy tsentr "Akademiya” [in Russian].

3. Huzieieva, T.S. (2004). Suchasni tendentsii psykhichnoho zdorovia naselennia ta zakhody shchodo yoho vdoskonalennia [Current trends in mental health of the population and measures to improve]. Psykhichne zdorovia - Mental Health, 2 (3), 4-8 [in Ukrainian].

4. Degarle, P. (2001). Preservation of psychic health in the world: challenges and priorities in developing countries.

5. Davydova, N.S. (2004). Mozhlyvi kryterii prohnozuvannia porushennia mozkovoho krovoobihu pid chas narkozu [Possible criteria for predicting cerebrovascular accidents during anesthesia]. Otdeleniye intensivnoy terapii - Intensive Care Unit, 5, 232-234 [in Russian].

6. Zakon Ukrainy "Osnovy zakonodavstva Ukrainy pro okhoronu zdorovia” Redaktsiinyi vyd 31.12.2017 zhidno Zakonu Ukrainy vid 14.11.2017 № 2206. Zakon Ukrainy vid 19.11.1992 № 2801-XII. [Law of Ukraine "Basics of the legislation of Ukraine on health care" Editorial view 31.12.2017 according to the Law of Ukraine from 14.11.2017 No. 2206. Law of Ukraine of 19.11.1992 No. 2801-XII.] [in Ukrainian].

7. Kiseleva, O.G. (2006). Profilaktika stomatologicheskogo strakha. Chast I. [Dental fear prevention. Part I.] Detskaya stomatologiya $i$ profilaktika - Pediatric Dentistry and Prevention, 1-2, 54-61 [in Russian].

8. Kuznetsov, V.M., Prohno, O.I., Koval, P.B., \& Kosenko, O.M. (2015). Spivpratsia "dytyna-stomatolohbatky" - harantiia uspishnoho likuvannia [Cooperation "child-dentist-parents" - guarantee successful treatment]. Neonatolohichna khirurhiia ta perynatalna medytsyna - Neonatology Surgery and Perinatal Medicine, 4 (18), 19-26 [in Ukrainian].

9. Mikadze, U.V. (2008). Neyropsikhologiya detskogo vozrasta [Childhood neuropsychology]. Saint-Petersburg: Piter [in Russian].

10. Maksimenko, S.D. (2004). Zahalna psykholohiia: navch. posib. Vyd. 2, pererob. ta dop. [General Psychology: Tutorial. 2 ed. rev. and compl.] Kyiv: Tsentr navchalnoi literatury [in Ukrainian].

11. Poriadin, G.V. (Ed.). (2009). Stress i patologiya: metodicheskay a razrabotka dlya samostoyatelnoy raboty studentov lechebnogo $i$ pediatricheskogo fakultetov [Stress and pathology: methodological development for independent work of students of medical and pediatric faculties]. Moscow: RGMU [in Russian].

12. Burkhart, C.S., \& Steiner, L.A. (2012). Can postoperative cognitive dysfunction be avosded? Hosp. Pract, 40 (1), 214-223.

13. Lobov, M., Knyazev, A., \& Ovezov, A. (2010). Perioperatsionnaya profilaktika ranney kognitivnoy disfunktsii u detey [Perioperative prevention of early cognitive dysfunction in children]. Meditsina intensivnoy terapii - Intensive Care Medicine, 36 (2), 276 [in Russian]. 14. Meixensberger, J., Dings, J., \& Hamelbeck, B. (1995). Monitoring of cerebral oxygenation by near infrared spectroscopy vs brain tissue PO2 and cerebral perfusion pressure following severe head injury. Proceedings of the Int. Cereb. Hemodyn. Symp., of North America.

15. Mchedlishvili, G.I. (1998). Arterial behavior and blood circulation in the brain. NY.

16. Prokhno, O.I. (2014). Clinical and psychological basis of indications for oral cavity sanation in children of different ages under general anesthesia. Proceedings of the International conference Materials Methods and Technologies. Bulgaria.

17. Reynolds, E.O.R., Wyatt, J.S., Azzopardi, D., Delpy, D.T., Cady, B., Cope, M., \& Wray, S. (1988). New noninvasive methods for assessing brain oxygenation and haemodynamics. Brit. Med. Bull., 1052-1075.

18. Verhagen, E.A., Van Braeckel, K.N., van der 
Veere, C.N., Croen, H., Dijk, P.H., Hulzebos, C.V. \& Bos, A.F. (2015). Cerebral oxygenation is associated with neurodevelopmental outcome of preterm children at age 2-3 years. Dev. Med. Child Neurol., 57 (5), 449-455.
19. Yakhno, N.N., \& Zakharov, V.V. (2010). Kognitivnyye narusheniya. Nevrologiya: natsionalnoye rukovodstvo [Cognitive impairment. Neurology: national leadership]. [in Russian].

Робота є фрагментом НДР «Діагностика, лікування і профілактика захворювань твердих тканин зубів на різних етапах їх розвитку у дітей», номер державної реєстрації 0116U000122. 